\title{
Development of Empirical Correlations Between Shear Wave Velocity and Standard Penetration Value: A Case Study of Rajshahi District, Bangladesh
}

\author{
Md Ashikuzzaman", 3, *, Md Shakil Ar Salan², Md Ashikur Rahman³, Md Mahmudul Hasan ${ }^{3}$ \\ ${ }^{1}$ Department of Civil Engineering, Zhejiang University, Hangzhou, China, \\ ${ }^{2}$ Urban Planner, Committed Development Limited (CDL), Rajshahi, Bangladesh \\ ${ }^{3}$ Department of Civil Engineering, Rajshahi University of Engineering \& Technology, Rajshahi, Bangladesh
}

\section{Email address:}

ashik.amjr120116@gmail.com (Md Ashikuzzaman),shakil.ruet@hotmail.com (Md S. Ar Salan), ashikurrahmanruet13@gmail.com (Md A. Rahman),mahmudulhp13@gmail.com (Md M. Hasan)

${ }^{*}$ Corresponding author

\section{To cite this article:}

Md Ashikuzzaman, Md Shakil Ar Salan, Md Ashikur Rahman, Md Mahmudul Hasan. Development of Empirical Correlations Between Shear Wave Velocity and Standard Penetration Value: A Case Study of Rajshahi District, Bangladesh. American Journal of Mechanical and Industrial Engineering. Vol. 6, No. 1, 2021, pp. 1-6. doi: 10.11648/j.ajmie.20210601.11

Received: August 15, 2020; Accepted: August 24, 2020; Published: March 4, 2021

\begin{abstract}
In seismic response investigation, shear wave velocity, Vs shows a vigorous role as an input factor. Enormous methodologies have been developed and tested to directly determine this key factor. Direct measurement of $\mathrm{V}_{\mathrm{s}}$ is timeconsuming as well as highly expensive. As a result, researchers from different regions have tried to reduce the difficulties associated with the measurement and developed empirical relationships between $V_{S}$ and other geotechnical characteristics of the soil, such as SPT calculation, depth, vertical effective pressure, etc. In this paper, the empirical correlation between shear wave velocity and standard penetration number (SPT-N) has been investigated for several soil categories: all soils, sand, silt and clay-type soils. Study area selected for this analysis are Bagha, Bagmara, Charghat, Durgapur, Godagari, Paba, Puthia, Tanore and Rajshahi City Corporation (RCC) area consisting of 36 borehole dataset. Combining all the data, an approach is made to correlate the Vs with the SPT-N. The square value of the coefficient $\left(\mathrm{R}^{2}\right)$ of correlation shows good agreement with the subsoil. Regression analysis is used to propose an empirical relation for this zone which would be helpful for foundation engineers to have the idea on earthquake response analysis of subsoil.
\end{abstract}

Keywords: Standard Penetration Test (SPT)-N, Shear Wave Velocity, Regression Analysis

\section{Introduction}

Shear wave velocity (Vs) is the significant parameter for the dynamic characterization and analysis of subsurface. Field measurement of such parameter is expensive as well as time consuming. Vs is estimated as field study and laboratory investigation by using empirical correlations. Laboratory investigation is worked out to determine shear wave velocity with SPT-N value. SPT-N value is locally and internationally available and can be determined very easily in the field.

In the current study, a set of correlation equations between standard penetrations tests (SPT-N values) and shear wave velocity (Vs) for different groups of soils is established for
Rajshahi district, Bangladesh. Rajshahi District located in north-western part of Bangladesh beside Padma River. It is a part of the Rajshahi Division and third largest city of Bangladesh. Rajshahi district is divided into 9 Upazila named: Bagha, Bagmara, Charghat, Durgapur, Godagari, Paba, Puthia, Tanore and Rajshahi City Corporation (RCC). Study area selected for this analysis are shown in figure 1.

Empirical correlations have three different advantages i.e., convenience, efficiency and economy. Empirical correlations have been used worldwide but before using it should be checked against validation because these equations are site 
dependent and some researchers have tried to formulate the equations which may be applicable for all region $[1,2]$. This analytical research deals with the development of empirical correlations between Vs and SPT-N for different upazillas of Rajshahi and finally for Rajshahi District (RD) collecting four borehole profile from each Upazila, a total of 36 borehole profile.

\section{Development of Empirical Correlations}

For evaluation of shear wave velocities and associated geotechnical parameters, the following a power-equation model is practiced widely:

$$
\mathrm{V}_{\mathrm{S}}=\mathrm{AN}^{\mathrm{B}}
$$

Where, $\mathrm{A}$ is a constant controlling the amplitude, $\mathrm{N}$ is the uncorrected SPT value and B is another constant depending on curvature relationship. Also, it is to be noted here, other factors such as depth, overburden pressure, geological age, fine content and soil types which may also govern or modify the relationships has-not been included in this study.

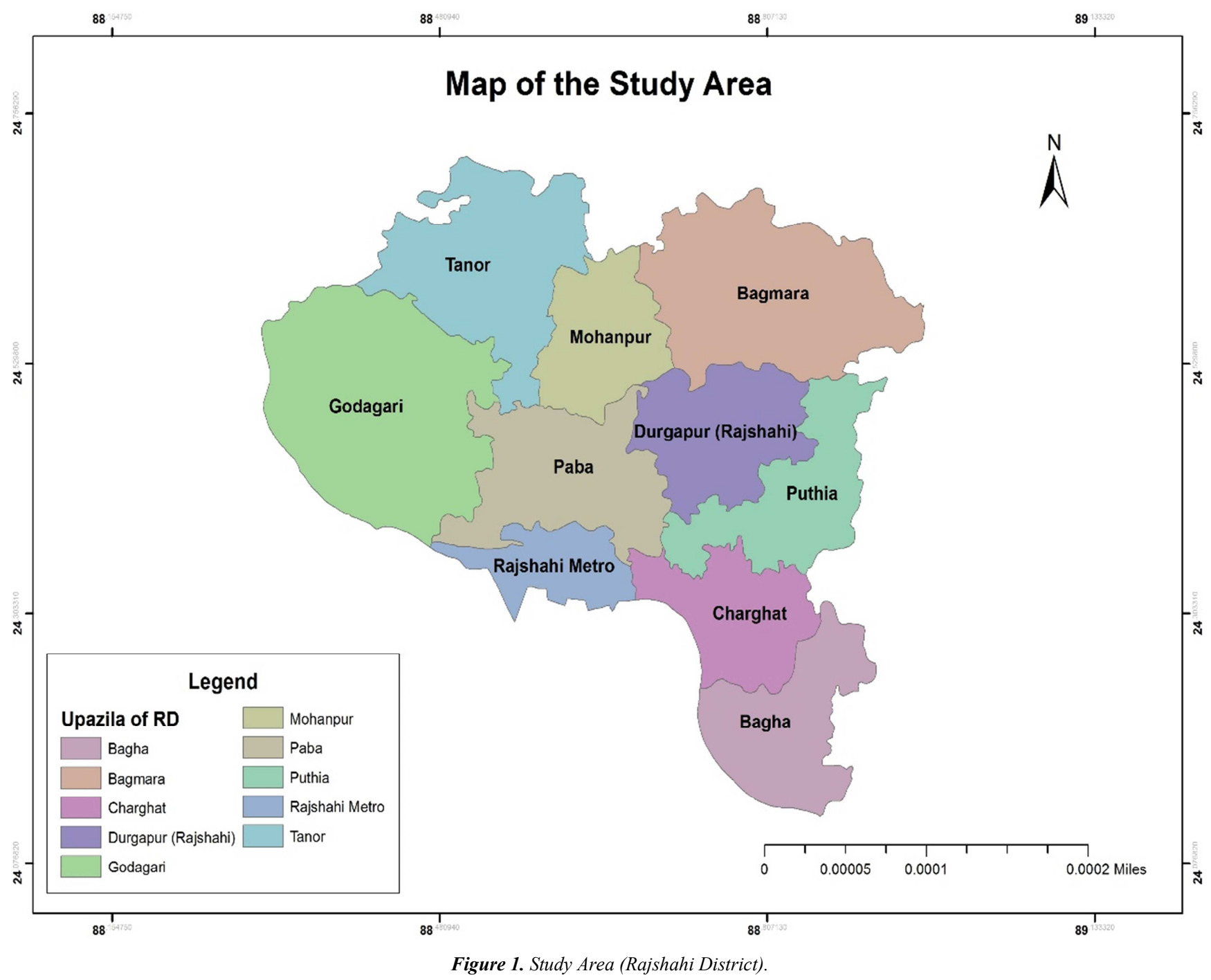

In the present world, Earthquake hazards is one of the crucial issue and Vs in this issue has intensive power to evaluate assessment of any area. Four borehole profiles from each areas in total 36 were utilized for the graphical presentation of existing relations (table 1) with the help of Microsoft Excel 2013. Regression analysis in terms of $\mathrm{R}$ squared value is carried out to establish and check the accuracy of the equation for every selected areas for all soils, sands, clays and silts as a power law form $\left(\mathrm{Vs}_{\mathrm{s}}=\mathrm{AN}^{\mathrm{B}}\right)$. Then, taking all the SPT-N values from these areas (varies from 1 to 49) were plotted for Rajshahi District. 
Table 1. Existing correlations between shear wave velocity and standard penetration number (SPT-N).

\begin{tabular}{|c|c|c|c|c|}
\hline \multirow{2}{*}{ Author(s) } & \multicolumn{4}{|l|}{ Shear Wave Velocity, Vs } \\
\hline & All Soils & Sands & Clays & Silts \\
\hline Ohba and Toriumi (1970) [3] & $\mathrm{V}_{\mathrm{s}}=84 \mathrm{~N}^{0.31}$ & -- & -- & -- \\
\hline Imai and Yoshimura (1970) [4] & $\mathrm{V}_{\mathrm{s}}=76 \mathrm{~N}^{0.33}$ & -- & -- & -- \\
\hline Fujiwara (1972) [5] & $\mathrm{V}_{\mathrm{s}}=92.1 \mathrm{~N}^{0.337}$ & -- & -- & -- \\
\hline Ohsaki and Iwasaki (1973) [6] & $\mathrm{V}_{\mathrm{s}}=82 \mathrm{~N}^{0.39}$ & $\mathrm{~V}_{\mathrm{s}}=59.4 \mathrm{~N}^{0.47}$ & -- & -- \\
\hline Imai and Tonouchi (1982) [7] & $\mathrm{V}_{\mathrm{s}}=91 \mathrm{~N}^{0.337}$ & $\mathrm{~V}_{\mathrm{s}}=80.6 \mathrm{~N}^{0.331}$ & $\mathrm{~V}_{\mathrm{s}}=80.2 \mathrm{~N}^{0.292}$ & -- \\
\hline Ohta and Goto (1978) [8] & $\mathrm{V}_{\mathrm{s}}=85.35 \mathrm{~N}^{0.348}$ & $\mathrm{~V}_{\mathrm{s}}=88 \mathrm{~N}^{0.34}$ & -- & -- \\
\hline Seed and Idriss (1981) [9] & $\mathrm{V}_{\mathrm{s}}=61 \mathrm{~N}^{0.5}$ & -- & -- & -- \\
\hline Imai and Tonouchi (1982) [7] & $\mathrm{V}_{\mathrm{s}}=97 \mathrm{~N}^{0.314}$ & -- & -- & -- \\
\hline Sykora and Stoke (1983) [10] & -- & $\mathrm{V}_{\mathrm{s}}=100.5 \mathrm{~N}^{0.29}$ & -- & -- \\
\hline Jinan (1987) [11] & $\mathrm{V}_{\mathrm{s}}=116.1(\mathrm{~N}+0.3185)^{0.202}$ & -- & -- & -- \\
\hline Lee (1990) [12] & -- & $\mathrm{V}_{\mathrm{s}}=57.4 \mathrm{~N}^{0.49}$ & $\mathrm{~V}_{\mathrm{s}}=114.43 \mathrm{~N}^{0.31}$ & $\mathrm{~V}_{\mathrm{s}}=105.6 \mathrm{~N}^{0.32}$ \\
\hline Sisman (1995) [13] & $\mathrm{V}_{\mathrm{s}}=32.8 \mathrm{~N}^{0.51}$ & -- & -- & -- \\
\hline Iyisan (1996) [14] & $\mathrm{V}_{\mathrm{s}}=51.5 \mathrm{~N}^{0.516}$ & -- & -- & -- \\
\hline Jafari et al. (1997) [15] & $\mathrm{V}_{\mathrm{s}}=22 \mathrm{~N}^{0.85}$ & -- & -- & -- \\
\hline Kiku et al. (2001) [16] & $68.3 \mathrm{~N}^{0.292}$ & -- & -- & -- \\
\hline Jafari et al. (2002) [17] & -- & $\mathrm{V}_{\mathrm{s}}=19 \mathrm{~N}^{0.85}$ & $\mathrm{~V}_{\mathrm{s}}=27 \mathrm{~N}^{0.73}$ & $\mathrm{~V}_{\mathrm{s}}=22 \mathrm{~N}^{0.77}$ \\
\hline Kanai (1996) [18] & $V_{s}=19 N^{0.6}$ & -- & -- & -- \\
\hline Shibata (1970) [19] & -- & $\mathrm{V}_{\mathrm{s}}=32 \mathrm{~N}^{0.5}$ & -- & -- \\
\hline Ohta et al. (1972) [20] & -- & $\mathrm{V}_{\mathrm{s}}=87 \mathrm{~N}^{0.36}$ & -- & -- \\
\hline Dikmen (2009) [21] & $\mathrm{V}_{\mathrm{s}}=58 \mathrm{~N}^{0.39}$ & $\mathrm{~V}_{\mathrm{s}}=73 \mathrm{~N}^{0.33}$ & $\mathrm{~V}_{\mathrm{s}}=44 \mathrm{~N} 0.48$ & $\mathrm{~V}_{\mathrm{s}}=60 \mathrm{~N}^{0.36}$ \\
\hline Athanasopoulos (1995) [22] & $V_{s}=107.6 N^{0.36}$ & -- & $\mathrm{V}_{\mathrm{s}}=76.55 \mathrm{~N}^{0.445}$ & -- \\
\hline Okamoto et al. (1989) [23] & -- & $\mathrm{V}_{\mathrm{s}}=125 \mathrm{~N}^{0.3}$ & -- & -- \\
\hline Kalteziotis et al. (1992) [24] & $\mathrm{V}_{\mathrm{s}}=76.2 \mathrm{~N}^{0.24}$ & -- & $\mathrm{V}_{\mathrm{s}}=76.6 \mathrm{~N}^{0.45}$ & -- \\
\hline Hanumanthrao and Ramana (2008) [25] & $\mathrm{V}_{\mathrm{s}}=82.6 \mathrm{~N}^{0.43}$ & $\mathrm{~V}_{\mathrm{s}}=86 \mathrm{~N}^{0.42}$ & -- & -- \\
\hline Hasancebi and Ulusay (2007) [26] & $\mathrm{V}_{\mathrm{s}}=90 \mathrm{~N}^{0.309}$ & $\mathrm{~V}_{\mathrm{s}}=90.82 \mathrm{~N}^{0.319}$ & $\mathrm{~V}_{\mathrm{s}}=97.89 \mathrm{~N}^{0.269}$ & -- \\
\hline Tsiambaos and Sabatakakis (2010) [27] & -- & -- & -- & $\mathrm{V}_{\mathrm{s}}=99.45 \mathrm{~N}^{0.364}$ \\
\hline Chatterjee and Choudhury (2013) [28] & -- & -- & -- & $\mathrm{V}_{\mathrm{s}}=58 \mathrm{~N}^{0.455}$ \\
\hline Lee (1988) [29] & -- & -- & -- & $\mathrm{V}_{\mathrm{s}}=135.67+9.11 \mathrm{~N}$ \\
\hline Lee (1988) [29] & -- & -- & -- & $\mathrm{V}_{\mathrm{s}}=100 \mathrm{~N}^{0.38}$ \\
\hline Uma Maheswari et al. (2010) [30] & $\mathrm{V}_{\mathrm{s}}=95.641 \mathrm{~N}^{0.3013}$ & $\mathrm{~V}_{\mathrm{s}}=100.53 \mathrm{~N}^{0.265}$ & $\mathrm{~V}_{\mathrm{s}}=89.31 \mathrm{~N}^{0.358}$ & -- \\
\hline Pitilakis et al. (1992) [31] & $\mathrm{V}_{\mathrm{s}}=162 \mathrm{~N}^{0.17}$ & -- & $\mathrm{V}_{\mathrm{s}}=165.7 \mathrm{~N}^{0.19}$ & -- \\
\hline JRA (1980) [32] & -- & $\mathrm{V}_{\mathrm{s}}=80 \mathrm{~N}^{0.33}$ & $\mathrm{~V}_{\mathrm{s}}=100 \mathrm{~N}^{0.33}$ & -- \\
\hline Fatehnia et al. (2015) [33] & -- & $\mathrm{V}_{\mathrm{s}}=77.1 \mathrm{~N}^{0.355}$ & $\mathrm{~V}_{\mathrm{s}}=77.1 \mathrm{~N}^{0.355}$ & -- \\
\hline Esfehanizadeh et al. (2015) [34] & -- & $\mathrm{V}_{\mathrm{s}}=107.2 \mathrm{~N}^{0.34}$ & -- & -- \\
\hline Chien et al. (2000) [35] & -- & $\mathrm{V}_{\mathrm{s}}=22 \mathrm{~N}^{0.76}$ & -- & -- \\
\hline Raptakis et al. (1995) [36] & -- & $\mathrm{V}_{\mathrm{s}}=100 \mathrm{~N}^{0.24}$ & $\mathrm{~V}_{\mathrm{s}}=184.2 \mathrm{~N}^{0.17}$ & -- \\
\hline Yokota et al. (1991) [37] & $\mathrm{V}_{\mathrm{s}}=121 \mathrm{~N}^{0.27}$ & -- & -- & -- \\
\hline Imai and Yoshimura (1976) [38] & $\mathrm{V}_{\mathrm{s}}=92 \mathrm{~N}^{0.329}$ & -- & -- & -- \\
\hline Mhaske and Choudhury (2011) [39] & $V_{s}=72 N^{0.40}$ & -- & -- & -- \\
\hline Sykoro and Stokoe (1983) [10] & $\mathrm{V}_{\mathrm{s}}=100.5 \mathrm{~N}^{0.329}$ & -- & -- & -- \\
\hline
\end{tabular}

\section{Results and Discussion}

It is noticeable from the table that, researchers have given correlations on four distinct category: (a) All soils, (b) Sands, (c) Clay and (d) Silt. Using these correlations given in table 1, following graphs are plotted according to the collected bore $\log$ SPT data for Bagha Upazila. Along with graphs, equations and corresponding $\mathrm{R}^{2}$ value for each category has also been incorporated here. 
(a)

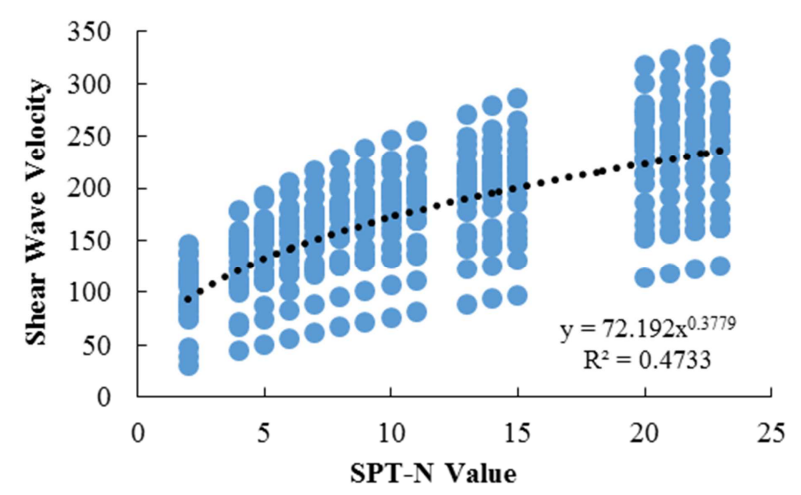

(c)

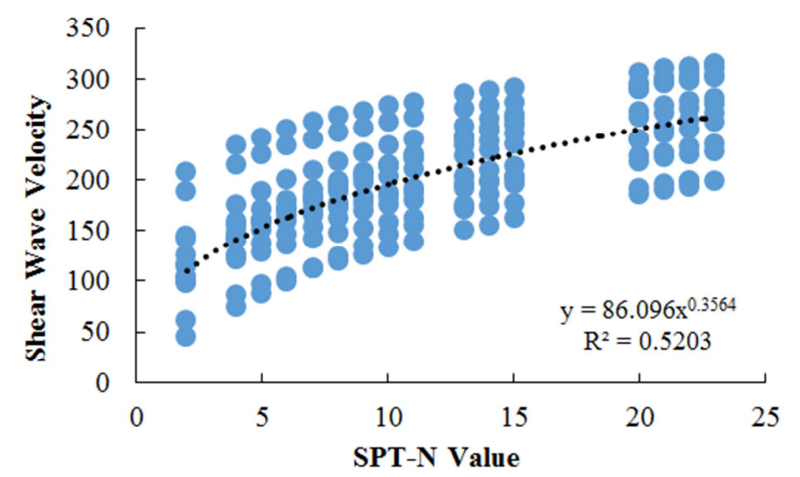

(b)

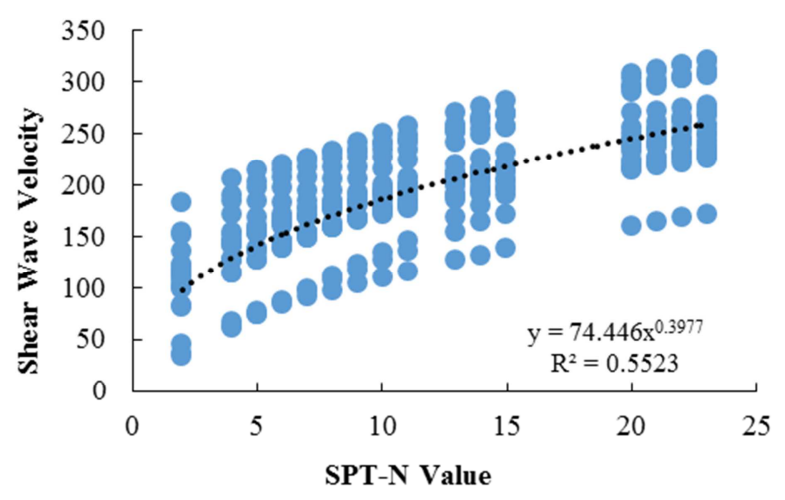

(d)

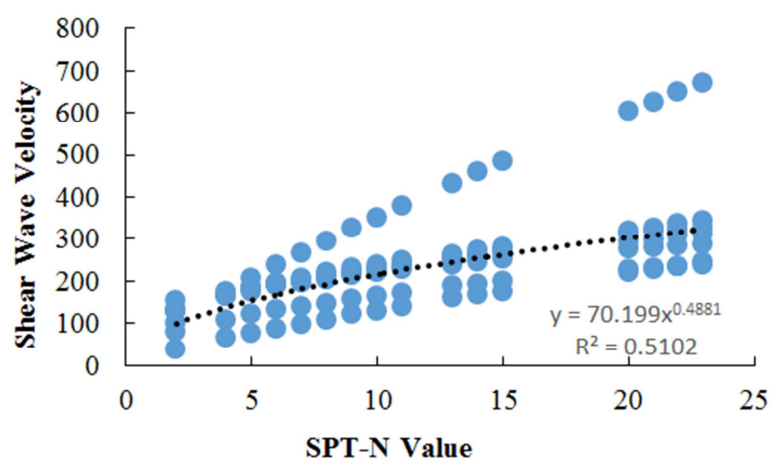

Figure 2. Shear wave velocity and SPT correlations for Bagha Upazila.

Now, same analysis is performed for other soil profile located in other Upazila and their analysis findings are shown in the following table:

Table 2. Shear wave velocity equation and corresponding $R^{2}$ value for study area.

\begin{tabular}{llll}
\hline Study Area & Type of soil & Equation & R value \\
\hline \multirow{3}{*}{ Bagha } & All soils & $\mathrm{V}_{\mathrm{s}}=72.192 \mathrm{~N}^{0.3779}$ & 0.4733 \\
& Sands & $\mathrm{V}_{\mathrm{s}}=74.446 \mathrm{~N}^{0.3977}$ & 0.5523 \\
& Clays & $\mathrm{V}_{\mathrm{s}}=86.096 \mathrm{~N}^{0.3564}$ & 0.5203 \\
& Silts & $\mathrm{V}_{\mathrm{s}}=70.199 \mathrm{~N}^{0.4881}$ & 0.5102 \\
All soils & $\mathrm{V}_{\mathrm{s}}=72.189 \mathrm{~N}^{0.3779}$ & 0.5613 \\
Bagmara & Sands & $\mathrm{V}_{\mathrm{s}}=74.446 \mathrm{~N}^{0.3977}$ & 0.6345 \\
& Clays & $\mathrm{V}_{\mathrm{s}}=85.475 \mathrm{~N}^{0.3603}$ & 0.6092 \\
& Silts & $\mathrm{V}_{\mathrm{s}}=69.61 \mathrm{~N}^{0.4933}$ & 0.5944 \\
& All soils & $\mathrm{V}_{\mathrm{s}}=72.198 \mathrm{~N}^{0.3779}$ & 0.4555 \\
Charghat & Sands & $\mathrm{V}_{\mathrm{s}}=74.446 \mathrm{~N}^{0.3977}$ & 0.5389 \\
& Clays & $\mathrm{V}_{\mathrm{s}}=86.329 \mathrm{~N}^{0.355}$ & 0.5031 \\
& Silts & $\mathrm{V}_{\mathrm{s}}=70.64 \mathrm{~N}^{0.4851}$ & 0.4884 \\
All soils & $\mathrm{V}_{\mathrm{s}}=72.211 \mathrm{~N}^{0.3779}$ & 0.6837 \\
Surgapur & $\mathrm{V}_{\mathrm{s}}=74.446 \mathrm{~N}^{0.3977}$ & 0.7505 \\
& Sands & $\mathrm{V}_{\mathrm{s}}=85.202 \mathrm{~N}^{0.3655}$ & 0.738 \\
& Clays & $\mathrm{V}_{\mathrm{s}}=70.375 \mathrm{~N}^{0.493}$ & 0.6877 \\
Silts & $\mathrm{V}_{\mathrm{s}}=72.185 \mathrm{~N}^{0.378}$ & 0.5835 \\
Godagari & All soils & $\mathrm{V}_{\mathrm{s}}=74.446 \mathrm{~N}^{0.3977}$ & 0.6728 \\
& Sands & $\mathrm{V}_{\mathrm{s}}=84.39 \mathrm{~N}^{0.3671}$ & 0.6553 \\
& Clays & $\mathrm{V}_{\mathrm{s}}=69.1 \mathrm{~N}^{0.497}$ & 0.6085 \\
& Silts & $\mathrm{V}_{\mathrm{s}}=72.192 \mathrm{~N}^{0.3779}$ & 0.4796 \\
& All soils & $\mathrm{V}_{\mathrm{s}}=74.446 \mathrm{~N}^{0.3977}$ & 0.5594 \\
& Sands & $\mathrm{V}_{\mathrm{s}}=86.037 \mathrm{~N}^{0.3567}$ & 0.5276 \\
& Clays & $\mathrm{V}_{\mathrm{s}}=70.147 \mathrm{~N}^{0.4886}$ & 0.516 \\
\hline
\end{tabular}




\begin{tabular}{llll}
\hline Study Area & Type of soil & Equation & $\mathbf{R}^{2}$ value \\
\hline \multirow{4}{*}{ Puthia } & All soils & $\mathrm{V}_{\mathrm{s}}=72.199 \mathrm{~N}^{0.3779}$ & 0.4229 \\
& Sands & $\mathrm{V}_{\mathrm{s}}=74.446 \mathrm{~N}^{0.3977}$ & 0.4799 \\
& Clays & $\mathrm{V}_{\mathrm{s}}=86.481 \mathrm{~N}^{0.3539}$ & 0.4491 \\
& Silts & $\mathrm{V}_{\mathrm{s}}=71.033 \mathrm{~N}^{0.4817}$ & 0.4639 \\
& All soils & $\mathrm{V}_{\mathrm{s}}=72.223 \mathrm{~N}^{0.3778}$ & 0.5969 \\
RCC & Sands & $\mathrm{V}_{\mathrm{s}}=74.446 \mathrm{~N}^{0.3977}$ & 0.6467 \\
& Clays & $\mathrm{V}_{\mathrm{s}}=86.593 \mathrm{~N}^{0.3552}$ & 0.6196 \\
& Silts & $\mathrm{V}_{\mathrm{s}}=71.626 \mathrm{~N}^{0.4811}$ & 0.6173 \\
& All soils & $\mathrm{V}_{\mathrm{s}}=72.191 \mathrm{~N}^{0.3779}$ & 0.5121 \\
Tanore & Sands & $\mathrm{V}_{\mathrm{s}}=74.446 \mathrm{~N}^{0.3977}$ & 0.6007 \\
& Clays & $\mathrm{V}_{\mathrm{s}}=84.726 \mathrm{~N}^{0.3653}$ & 0.5796 \\
& Silts & $\mathrm{V}_{\mathrm{s}}=69.983 \mathrm{~N}^{0.4902}$ & 0.5427 \\
\hline
\end{tabular}

From table, taking "all soils" category into account, representative correlation for subsoil of Bagha Upazila is given by the equation $\mathrm{V}_{\mathrm{s}}=72.192 \mathrm{~N}^{0.3779}$ having $\mathrm{R}^{2}$ value of 0.4733. For the estimated correlations, the co-efficient of determination $\left(\mathrm{R}^{2}\right)$ is found to be relatively low; this may be due to limited data pairs. Similarly, among the derived correlations for Bagmara, Charghat, Durgapur, Godagari, Paba, Puthia, RCC and Tanore Upazila, $\mathrm{R}^{2}$ values are given as $0.5613,0.4555,0.6837,0.5835,0.4796,0.4229,0.5969$ and 0.6007 respectively. Also, considering soil profiles as sandy, clayey or silty, derived correlations along with their
$\mathrm{R}^{2}$ value would possibly be an important geological parameter for this zone.

Now, considering all the SPT data (36 Borehole profile) collected from nine different Upazila, graphs are plotted to find overall correlations for Rajshahi District. Using the correlations given in table 1 , graphs are plotted on the basis of four distinct category sated earlier. Governing equation along with $\mathrm{R}$ squared values are incorporated here also. Analysis results are shown in tabular format below:

Table 3. Shear wave velocity equation and corresponding $R^{2}$ value for Rajshahi District.

\begin{tabular}{llll}
\hline Name of the area & Types of soil & Equation & R squared value \\
\hline \multirow{3}{*}{ Rajshahi District } & All soils & $\mathrm{V}_{\mathrm{s}}=72.202 \mathrm{~N}^{0.3779}$ & 0.6256 \\
& Sands & $\mathrm{V}_{\mathrm{s}}=74.446 \mathrm{~N}^{0.3977}$ & 0.7261 \\
& Clays & $\mathrm{V}_{\mathrm{s}}=85.558 \mathrm{~N}^{0.362}$ & 0.7028 \\
& Silts & $\mathrm{V}_{\mathrm{s}}=69.644 \mathrm{~N}^{0.4956}$ & 0.6293 \\
\hline
\end{tabular}

\section{Conclusions}

The developed correlations relating shear wave velocity with SPT value is entirely based on SPT data set available. To quantify liquefaction assessment of the studied area shear wave velocity equations proposed in this study will play a significant role. From the present study, several conclusions can be drawn:

1) The proposed and developed equations are only applicable for the selected areas and Rajshahi District.

2) Number of borehole data set play a dominant role in the estimation of Shear wave velocity. More the number of borehole dataset would give more the accuracy of the regression curves.

3) Using as many equations also give more accuracy curve for the estimation of Vs.

4) The $R^{2}$ value shows good agreement with soil type's sand and clay. On the contrary, it also can be shown considering intermediate soil strata.

\section{Acknowledgements}

The authors would love to give heartiest thanks to the Department of Civil Engineering, RUET, Rajshahi-6204 and
Mahananda Design \& Consultant, Rajshahi for giving the SPT-N database.

\section{References}

[1] Marto A, Tan CS, Leong TK. Universal correlation of shear wave velocity and standard penetration resistance. Electronic Journal of Geotechnical Engineering. 2013; 18: 2727-38.

[2] Sil A, Haloi J. Empirical correlations with standard penetration test (SPT)-N for estimating shear wave velocity applicable to any region. International Journal of Geosynthetics and Ground Engineering. 2017; 3: 22.

[3] Ohba S, Toriumi I. Dynamic response characteristics of Osaka Plain. Proceedings of the annual meeting AIJ (in Japanese) 1970.

[4] Imai T, Yoshimura Y. Elastic wave velocity and soil properties in soft soil. Tsuchito-Kiso. 1970; 18: 17-22.

[5] Fujiwara T. Estimation of ground movements in actual destructive earthquakes. Proceedings of the fourth European symposium on earthquake engineering, London 1972. p. 12532.

[6] Ohsaki Y, Iwasaki R. On dynamic shear moduli and Poisson's ratios of soil deposits. Soils and Foundations. 1973; 13: 61-73. 
[7] Imai T. Correlation of $\mathrm{N}$ value with $\mathrm{S}$-wave velocity and shear modulus. 1982.

[8] Ohta Y, Goto N. Empirical shear wave velocity equations in terms of characteristic soil indexes. Earthquake engineering \& structural dynamics. 1978; 6: 167-87.

[9] Seed HB, Idriss I. Evaluation of liquefaction potential sand deposits based on observation of performance in previous earthquakes. ASCE national convention (MO) 1981. p. 481544.

[10] Sykora D, Stokoe K. Correlations of in-situ measurements in sands of shear wave velocity. Soil Dynamics and Earthquake Engineering. 1983; 20: 125-36.

[11] Jinan Z. Correlation between seismic wave velocity and the number of blow of SPT and depth. Selected Papers from the Chinese Journal of Geotechnical Engineering. 1987: 92-100.

[12] Lee SHH. Regression models of shear wave velocities in Taipei basin. Journal of the Chinese Institute of Engineers. 1990; 13: 519-32.

[13] Sisman H. An investigation on relationships between shear wave velocity, and SPT and pressuremeter test results. Master of Science Thesis, Ankara University, Turkey. 1995.

[14] Iyisan R. Correlations between shear wave velocity and in-situ penetration test results. Teknik Dergi-tmmob Insaat Muhendisleri Odasi. 1996; 7: 371-4.

[15] Jafari M, Asghari A, Rahmani I. Empirical correlation between shear wave velocity (Vs) and SPT-N value for south of Tehran soils. Proceedings of the 4th international conference on civil engineering, Tehran, Iran 1997.

[16] Kiku H. In-situ penetration tests and soil profiling in Adapazari, Turkey. Proc 15th ICSMGE TC4 Satellite Conference on Lessons Learned from Recent Strong Earthquakes, August 25, 2001, Istanbul, Turkey 2001. p. 25965 .

[17] Jafari MK, Shafiei A, Razmkhah A. Dynamic properties of fine grained soils in south of Tehran. 2002.

[18] Kanai K. Conf. on Cone Penetrometer The Ministry of Public Works and Settlement (Ankara, Turkey). presented by Y Sakai. 1968.

[19] Shibata T. Analysis of liquefaction of saturated sand during cyclic loading. Disaster Prevention Res Inst Bull. 1970; 13: 563-70.

[20] Ohta T, Hara A, Niwa M, Sakano T. Elastic shear moduli as estimated from $\mathrm{N}$-value. Proceedings 7 th annual convention of Japan society of soil mechanics and foundation engineering 1972. p. $265-8$.

[21] Dikmen Ü. Statistical correlations of shear wave velocity and penetration resistance for soils. Journal of Geophysics and Engineering. 2009; 6: 61-72.

[22] Athanasopoulos G. Empirical correlations Vso-NSPT for soils of Greece: A comparative study of reliability. WIT Transactions on The Built Environment. 1970; 15.

[23] Okamoto T, Kokusho T, Yoshida Y, Kusuonoki K. Comparison of surface versus subsurface wave source for $\mathrm{P}-\mathrm{S}$ logging in sand layer. Proc 44th Ann Conf JSCE 1989. p. 9967.
[24] Kalteziotis N, Sabatakakis N, Vassiliou J. Evaluation of dynamic characteristics of Greek soil formations. Second hellenic conference on geotechnical engineering 1992. p. 23946.

[25] Hanumantharao C, Ramana G. Dynamic soil properties for microzonation of Delhi, India. Journal of earth system science. 2008; 117: 719-30.

[26] Hasancebi N, Ulusay R. Empirical correlations between shear wave velocity and penetration resistance for ground shaking assessments. Bulletin of Engineering Geology and the Environment. 2007; 66: 203-13.

[27] Tsiambaos G, Sabatakakis N. Empirical estimation of shear wave velocity from in situ tests on soil formations in Greece. Bulletin of Engineering Geology and the Environment. 2011; 70: 291-7.

[28] Chatterjee K, Choudhury D. Variations in shear wave velocity and soil site class in Kolkata city using regression and sensitivity analysis. Natural hazards. 2013; 69: 2057-82.

[29] Lee S. Regression model for shear wave velocity of sandy and silty soils of Taipei basin. Proc of the CCNAA-AIT Joint Seminar/Workshop on Research and Application for Multiple Hazards Mitigation, Taipei 1988. p. 489-94.

[30] Maheswari RU, Boominathan A, Dodagoudar G. Use of surface waves in statistical correlations of shear wave velocity and penetration resistance of Chennai soils. Geotechnical and Geological Engineering. 2010; 28: 119-37.

[31] Pitilakis K, Anastasiadis A, Raptakis D. Field and laboratory determination of dynamic properties of natural soil deposits. Proceedings of the 10th world conference on earthquake engineering 1992. p. 1275-80.

[32] Association JR. Specification and interpretation of bridge design for highway-Part V: resilient design. 1980.

[33] Fatehnia M, Hayden M, Landschoot M. Correlation between shear wave velocity and SPT-N values for North Florida soils. Electron J Geotech Eng. 2015; 20: 12421-30.

[34] Esfehanizadeh M, Nabizadeh F, Yazarloo R. Correlation between standard penetration (N SPT) and shear wave velocity (V S) for young coastal sands of the Caspian Sea. Arabian Journal of Geosciences. 2015; 8: 7333-41.

[35] Chien L, Lin M, Oh Y. Shear wave velocity and SPT-N values of in-situ reclaimed soil in west Taiwan. GEOTECHNICAL ENGINEERING. 2000; 31: 63-78.

[36] Raptakis D, Anastasiadis S, Pitilakis K, Lontzetidis K. Shear wave velocities and damping of Greek natural soils. Proceedings of the 10th European conference on earthquake engineering 1994. p. 477-82.

[37] Yokota K, Imai T, Konno M. Dynamic deformation characteristics of soils determined by laboratory tests. OYO Tec Rep. 1981; 3: 13-37.

[38] Imai T, Yoshimura M. the relation of mechanical properties of soils to $\mathrm{P}$ and $\mathrm{S}$ wave velocities for soil ground in Japan. Urana Research Institute, OYO Corporation, Japan. 1976.

[39] Mhaske SY, Choudhury D. Geospatial contour mapping of shear wave velocity for Mumbai city. Natural Hazards. 2011; 59: 317-27. 